\title{
Arven fra Nürnberg genoptaget i Kampala Martin Mennecke
}

For første gang siden Nürnberg-tribunalet efter Anden Verdenskrig bliver der igen mulighed for at straffe dem, der igangsætter angrebskrige. Hvad aggressionsforbrydelser præcis omfatter forbliver dog uvist efter ICC's første statuskonference siden Domstolens dannelse i 2002

For første gang siden det Internationale Militærtribunal i Nürnberg dømte tyske krigsforbrydere for at have overfaldet resten af Europa, skal det igen blive strafbart at føre ulovlige krige. Der vil stadig gå minimum syv år til dette bliver aktuelt, men det har taget 65 år overhovedet at komme hertil. Beslutningen om at videreføre arven fra Nürnberg er derfor ikke mindre end historisk.

Beslutningen blev truffet den 12. juni i år. Siden slutningen af maj var over 2.000 diplomater, folkeretseksperter og menneskerettighedsaktivister fra mere end 100 lande forsamlet til den Internationale Straffedomstol, ICC's første statuskonference. Konferencen fandt sted i Kampala, Uganda, og udgjorde det første forsøg siden Domstolens oprettelse i 2002 på at gøre status på ICC's betydning og virke.

Mødet samlede både tilhængere og modstandere af ICC og var åbent for alle FN's medlemslande. Danmark var med til at præge en del af konferencens forløb. Denne artikel skal fortælle, hvad der skete i Kampala og hvem der var med til at skrive historie.

\section{Kampala - ikke Haag}

Evalueringskonferencen blev allerede aftalt, da man i 1998 i Rom færdigforhandlede den traktat, som danner grundlag for ICC, den såkaldte Rom-statut. Det stod klart, at et så banebrydende projekt som en 
permanent straffedomstol for internationale forbrydelser vil bringe fundamentale udfordringer med sig, som man vil blive nødt til at reagere på for at sikre ICC's succes. En anden anledning til at mødes igen vil være at fortsætte med forhandlingerne de steder, hvor man i 1998 ikke kunne opnå enighed som for eksempel vedrørende ideen om at gøre overfald på andre lande strafbar som 'crime of aggression'. ICC's medlemslande mødes i forvejen hvert år en uge eller to i en samling kaldet 'Assembly of State Parties', men disse årlige forsamlinger er drevet af budgetforhandlinger og andre løbende opgaver. Evalueringskonferencen skulle fokusere på mere grundlæggende spørgsmål.

Domstolens sæde er i Haag - byen, hvori også andre internationale domstole er placeret, derunder FN's øverste juridiske organ, den Internationale Domstol, og det Internationale Straffetribunal for det tidligere Jugoslavien. Hvorfor flyttede man så statuskonferencen hele vejen til Afrika?

Af to grunde. For det første betragtede mange regeringer det som en velkommen lejlighed til at markere, at ICC også er Afrikas domstol og ikke bare et vestligt projekt.

Domstolens møder plejer at foregå i Haag eller New York, mens ICC har 31 afrikanske medlemslande og alle nuværende sager ved Domstolen vedrører afrikanske lande.

Den anden overvejelse bag afhol- delsen af konferencen i Kampala var, at man dermed flyttede et prestigefyldt, måske unikt ICC møde, til et land, hvor Domstolen faktisk er aktiv. Uganda er nemlig siden 2004 et af de såkaldte 'situationslande', hvor ICC's anklager undersøger alvorlige brud på folkeretten. Med konferencen i Uganda ønskede man at signalere især over for forbrydelsernes ofre, at ICC ikke bare var en institution langt væk i Haag, men en masse mennesker, der kom hele vejen til Uganda for at lære mere om ofrenes situation. Samtidigt var Ugandas regering selvfølgelig interesseret i den prestige, der fulgte med afholdelsen af mødet.

\section{De største udfordringer}

Efter den store åbningsdag med talere fra Ugandas præsident, Yoweri Museveni, Tanzanias præsident, Jakaya Kikwete, FNs generalsekretær, Ban Ki Moon, og hans forgænger Kofi Annan samt en række ICC repræsentanter, kom den egentlige konference i gang. På programmet stod den såkaldte 'stocktaking exercise', et forsøg på at drøfte nogle af de udfordringer som igennem Domstolens første år havde vist sig at være særlig krævende. Nogle iagttagere syntes, at denne 'stocktaking' kom for tidligt, fordi Domstolen ikke har fået afsluttet en enkelt sag endnu - men denne kritik overser, at ICC allerede nu påvirker konfliktsituationer og deres aktører. Under 
overskriften 'stocktaking' valgte ICC medlemslande at gøre status på fire underemner: 1) ofrenes rolle i Domstolens virke; 2) sammenhængen mellem fred og retfærdighed; 3) samarbejde mellem ICC medlemslande og Domstolen og 4) sammenhængen mellem de nationale retssystemer og ICC.

Ofrenes rolle i ICC's system er meget særlig. Forskellige retssystemer giver forskelligt rum til ofre i straffesager; i nogle lande er ofrene begrænset til en meget passiv rolle, mens de $i$ andre lande agerer som en aktiv part ved siden af anklageren. På det internationale plan havde man hidtil fulgt den første model og det er først med ICC's oprettelse, at dette ændrer sig. Her er ofrene berettiget til at være mere end bare ofre eller vidner, men kan selv, gennem juridiske rådgivere, spille en meget aktiv rolle i proceduren.

For nogle ICC medlemslande er dette fortsat en meget fremmed tanke, ikke mindst fordi der i ICC sammenhæng er tale om hundredetusinde om ikke millioner af ofre, og mange diplomater kun anser ofrenes involvering som en potentiel hindring for at få afsluttet sagerne på en hurtig og effektiv måde. Diskussionerne i Kampala kom ikke i dybden med den problemstilling; måske fordi emnet er for betændt. Hvilket land ville stille sig op ved denne specielle lejlighed og i et land, hvor der er tusindvis af disse ofre, og advare mod for meget ind- flydelse til ofrene? Resultatet blev en række af forudsigelige indlæg fra stater, der alle sammen fremhævede, hvor vigtig ofrenes rolle var. De egentlige udfordringer eller ofrenes egne erfaringer med og forventninger til ICC blev ikke diskuteret.

\section{Fred med forbrydere?}

Det andet 'stocktaking' emne handlede om de spændinger, der kan opstå ved at retsforfølge regeringsledere eller rebeller som krigsforbrydere og at afholde fredsforhandlinger med de selv-samme aktører.

I litteraturen bliver dette scenario ofte betegnet som 'peace v. justice'dilemma - et dilemma som består i, at man på den ene side ikke kan forvente, at de ansvarlige indgår en fredsaftale, hvis dette er ensbetydende med, at de efterfølgende bliver sendt direkte videre til Domstolen i Haag - men at man på den anden side ikke vil give straffrihed til dem, der har myrdet, plyndret og voldtaget.

Eller skal man måske hellere tilbyde alle involverede en amnesti og se fremad?

I mange af de seneste års konflikter er man stødt på denne problemstilling: Bosnien, Kosovo, Sierra Leone og Darfur. Endda i forhold til Israel og Palæstina blev der sagt fra amerikansk side, at man måtte vente til senere, før man kan tale om retsforfølgning af eventuelle krigsforbrydelser - først måtte der sluttes fred. 


\section{BAGGRUND}

Under statuskonferencen udløste dette emne en interessant diskussion, næsten mod alle forventninger. Emnet er stærkt betændt i ICC sammenhæng, fordi de afrikanske medlemslande via den Afrikanske Union i 2009 havde bedt FN's Sikkerhedsråd om at udsætte ICC's aktiviteter i Darfur - for at give plads og ro til fredsforhandlinger med Bashir-regimet. Denne forespørgsel har Sikkerhedsrådet siden ignoreret - til en voksende frustration for nogle af de afrikanske lande.

Forud for Kampala havde der derfor været lave forventninger til denne del af 'stocktaking' processen. Ikke desto mindre lykkedes det at holde en interessant og interaktiv debat. En række lande gentog bare deres velkendte synspunkter, men der kom også nogle nye refleksioner frem over, hvilke konsekvenser straffrihed kan have for igangværende konfliktsituationer. Dette skyldtes især, at debatten blev igangsat af et par oplægsholder med baggrund som anklagere eller fredsmæglere, som ikke begrænsede sig til floskler, men talte ud fra deres konkrete erfaringer.

\section{Uden egen politistyrke}

Det tredje fokusområde var samarbejdet mellem ICC's medlemslande og ICC. Dette lyder måske umiddelbart noget overraskende eller lavpraktisk, men det er i Domstolens virkelighed af helt central betyd- ning. ICC har ingen egen politistyrke eller efterretningstjeneste og er derfor i høj grad afhængig af samarbejdet med medlemslandene. $\mathrm{Og}$ dette er et påtrængende problem, fordi på nuværende tidspunkt er kun syv af de femten personer domstolen eftersøger under arrest i Haag. Under statuskonferencen afholdtes der en paneldebat om samarbejdet mellem Domstolen og medlemslande, som ledte til en åben diskussion blandt staterne. Mens mange medlemslande understregede vigtigheden af at efterfølge Domstolens henvendelser og arrestordrer, var der også lidt mere tilbageholdende bemærkninger fra forskellige afrikanske lade, der fremhævede, at ICC ikke er den eneste relevante institution i denne sammenhæng. Det lykkedes på grund af disse forskellige synspunkter heller ikke at vedtage en egentlig resolution for at styrke samarbejdet mellem ICC og medlemslande.

Det sidste emne i forbindelse med 'stocktaking' delen var 'complementarity', og her indtog Danmark en hel central rolle. ICC har i modsætning til andre internationale straffetribunaler som det for det tidligere Jugoslavien, ICTY, ikke en overordnet rolle i forhold til nationale domstole. Hvor ICTY og dens søsterinstitution for Rwanda, ICTR, kunne bestemme, hvilke sager, der skal høres foran internationale dommere og hvilke foran nationale dommere, så bygger ICC på en anderledes rolle- 
fordeling: ICC er komplementær til de nationale systemer Det betyder, at Domstolen kun kan høre sager, når det pågældende land ikke selv er i stand eller har viljen til at retsforfølge relevante forbrydelser.

Implementeringen af dette 'principle of complementarity' anses for helt centralt for ICC's virke og accept blandt staterne. For det første beskytter dette princip medlemslandenes suverænitet, i og med det er staterne selv, der får tildelt det primære ansvar for retsopgøret. For det andet sikrer 'complementarity', hvis det bliver gennemført i god tro, at retsopgøret foregår tæt på ofrene, på et sprog de forstår og i det samfund, forbrydelserne blev begået i. Endelig argumenteres det, at 'complementarity' kan fungere som et incitament for at styrke det nationale retsvæsen for at kunne gennemføre sagerne der, fordi stater nok helst vil være fri for ICC's besøg.

Det sidste er også essentielt, fordi ICC aldrig vil kunne retsforfølge mere end en håndfuld af gerningsmænd fra et relevant land - dem, der bærer det største ansvar.

Det er sådan, ICC er konstrueret. og det Domstolen har budget til resten må det nationale system tage sig af for at forhindre, at der opstår en situation, hvor langt de fleste krigsforbrydere og folkedræbere går straffri, og kun nogle få ledere bliver straffet.

Sammen med Sydafrika havde den danske regering forberedt diskussio- nerne om 'complementarity' som såkaldt 'focal point' på vegne af ICC's medlemslande.

\section{Danmarks rolle}

I Kampala var det kun få lande, som gav udtryk for en vis skepsis over for den linje, Danmark og Sydafrika havde lagt. Især Tyskland og Frankrig var bekymrede, at 'complementarity' debatten kunne flytte fokus fra, at de enkelte ICC medlemslande selv er forpligtede til at sikre retsforfølgelsen af internationale forbrydelser til, at ICC skal yde udviklingsbistand til disse lande. Desuden bør Domstolens fokus være at retsforfølge, ikke at yde bistand. Dette var dog heller ikke ideen bag det papir, Danmark sammen med Sydafrika havde udarbejdet forud for statuskonferencen. Det handler primært slet ikke om, hvorvidt Domstolen kan støtte lokale myndigheder, men om hvorvidt andre aktører donorlande, internationale organisationer og det internationale civilsamfund - kan støtte de lokale myndigheder i et land, hvor der er blevet begået ICC-forbrydelser.

Langt de fleste lande var enige om, at problemet er, at ICC alene ikke vil kunne løfte udfordringen: at sætte en stopper for straffrihed. ICC er begrænset i sit mandat og sine ressourcer. Derfor må en bæredygtig handlingsstrategi over for krigsforbrydelser og andre massive overgreb mod menneskerettigheder ska- 
bes i samarbejde med de relevante nationale myndigheder. Den støtte, der skulle til for at styrke nationale kapaciteter vil kun i meget begrænset omfang kunne komme fra selve ICC - den tysk-franske kritik overser dette. Snarere handler 'complementarity' debatten om, hvorvidt donorlande og andre internationale aktører kan arbejde mere målrettet på ikke bare at styrke den lokale retsorden - men gøre det med sigte på at sætte nationale myndigheder i stand til at retsforfølge ugerninger, der ellers vil gå ustraffet, fordi ICC ikke kan tage sig af mere end 5-8 enkeltsager fra en given konflikt. I de fleste tilfælde har nationale myndigheder i de relevante lande behov for ekstern bistand til at kunne forberede og gennemføre retssager foran nationale domstole.

Under mødet i Kampala bragte Danmark og Sydafrika forskellige aktører fra donorsiden sammen med ICC repræsentanter og ICC medlemslande for at igangsætte denne centrale debat. Det skabte stor interesse, fordi alle var enige $i$, at løftet om at bryde straffriheden for folkedrab og andre internationale forbrydelser kun vil kunne indfries, hvis det lykkes at føre tanken bag 'principle of complementarity' ud i livet.

Danmark og Sydafrika fik meget ros for deres pionerarbejde og støtte til at fortsætte med deres arbejde igennem staternes ICC samling, Assembly of State Parties. At 'compli- mentarity' emnet var et af de vigtigste emner under statuskonferencen viser sig også ved, at forskellige aktører, som for eksempel EuropaKommissionen og det meget anerkendte International Center for Transitional Justice allerede har igangsat opfølgningsinitiativer.

'Stocktaking' øvelsen var alt i alt en succes. Emner, der er helt centrale for ICC's virke og gennemslagskraft, blev diskuteret på engageret vis og med mere fokus og tid til rådighed, end der normalt er tilstede under de årlige samlinger af ICC's medlemslande. Det kunne ikke forventes, at kontroversielle og komplicerede emner som sammenspillet mellem 'fred' og 'retfærdighed' vil kunne diskuteres færdigt i Kampala, men det lykkedes at skabe et forum for en saglig og videreførende debat om disse udfordringer. For andre problemstillinger som 'complementarity' blev der lagt et grundlag for at følge op med konkrete tiltag i den nærmeste fremtid. ICC medlemslande må nu vise, at statuskonferencen virkelig kun var en mellemstation på vej hen imod bedre løsninger på de fire 'stocktaking' områder.

\section{Fndringer til Rom-statutten}

I slutningen af den første konferenceuge skiftede opmærksomheden fra de store, policy-baserede 'stocktaking' emner. ICC har indtil videre udelukkende haft mulighed for at 
retsforfølge krigsforbrydelser, forbrydelser mod menneskeheden og folkedrab i de lande, der har tilsluttet sig ICC, eller som er begået af borgere fra disse lande andre steder i verden. Op til statuskonferencen foreslog enkelte lande at udvide dette katalog med henholdsvis pirateri, terrorisme, brug af atomvåben og international narkohandel.

Ingen af disse forslag mødte dog tilstrækkelig meget støtte blandt de øvrige stater. Derfor aftalte man i stedet for at kigge på disse forslag igen efter konferencen, de første ændringsforslag til statutten, siden domstolen blev oprettet i 2002. Forud for denne konference havde medlemslande drøftet en række forskellige ideer for nye forbrydelser, som eventuelt skulle tilføjes til Domstolens kompetencekatalog.

I og med at ICC statutten dog sætter meget høje krav for, at nye forbrydelser træder i kraft, virker det meget usandsynligt, at bare en af disse handlinger vil blive strafbar foran ICC i nær fremtid. I Kampala var fokus derfor kun på to forbrydelser: et par tilføjelser til, hvad der udgør krigsforbrydelser og den såkaldte 'crime of aggression', også kaldet aggressionsforbrydelsen.

I forhold til krigsforbrydelser havde Belgien fremsat et forslag om at udvide kataloget for handlinger, der kunne straffes under ICC-statutten. Mere specifikt drejede det sig om brugen af giftige våben, gasser $\mathrm{og}$ ekspanderende kugler i ikke-inter- nationale konflikter. Dette forslag blev vedtaget, efter det blev skrevet ind $\mathrm{i}$ beslutningen, at bestemmelsen ikke finder anvendelse på situationer, hvor der er tale om retshåndhævelse som under afslutning af en gidseltagning.

Den anden bestemmelse, der diskuteredes som mulig ændring til ICC-statutten, handlede om, hvorvidt nye ICC medlemslande skulle beholde muligheden for at suspendere Domstolens muligheder for at retsforfølge krigsforbrydelser begået på deres territorium i syv år. Denne bestemmelse, Artikel 124 af ICC-statutten, var siden ICC's oprettelse kun blevet taget i brug af Frankrig og Columbia, og det virkede derfor ikke strengt nødvendigt at forny denne begrænsning på Domstolens kompetencer.

Forhandlingerne i Kampala viste $\mathrm{dog}$, at der var en række lande, der ikke er medlem af ICC endnu, der anså det som vigtigt, at de ved en eventuel tiltræeden i fremtiden også havde denne mulighed. I sidste omgang var det selvfølgelig medlemslandene, der skulle træffe beslutningen om Artikel 124 skulle fortsætte med at eksistere eller ej, men i og med at det er en overordnet målsætning at udvide antallet af ICC medlemslande, blev det vedtaget at forny undtagelsesbestemmelsen. Det blev dog aftalt, at Artikel 124 igen skal revurderes i 2015 .

I den anden uge skiftede al fokus til mødets uomstridte hovedemne: 
aggressionsforbrydelsen. Da ICC statutten blev forhandlet på plads $\mathrm{i}$ Rom i 1998, kunne man ikke enes om, hvordan denne forbrydelse skulle defineres. Det, man dengang var kommet frem til var at skrive det ind i traktaten, at Domstolen skulle have til opgave at dømme over aggressionsforbrydelsen - men kun fra den dag, der foreligger en definition. På den måde havde man dog samtidigt sikret, at diskussionen om aggressionsforbrydelsen ikke vil forsvinde; tværtimod stod det klart for alle, at dette ville blive et hovedemne for ICC's første statuskonference. Faktisk mødtes landene efterfølgende hvert år i en særlig arbejdsgruppe for at arbejde videre på en mulig definition for forbrydelsen. Det var denne arbejdsgruppes udkast til en definition, Kampala mødet tog afsæt i.

\section{Angrebskrig igen strafbar}

Forud for konferencen var der ikke mange iagttagere, der regnede med, at dette udkast havde en chance for at blive vedtaget. En gruppe af ICCvenlige stater udtrykte skepsis overfor, at Domstolen på det her tidlige tidspunkt i sin tilstedeværelse vil kunne klare sager om aggressionsforbrydelsen. Det blev argumenteret, at disse sager vil blive for politiserede og skadelige for Domstolen, ikke mindst fordi aggressionsforbrydelsen i modsætning til de andre ICC- forbrydelser ikke kan begås uden en stats indblanding - krigsforbrydelser, for eksempel, kan også begås af en enkelt soldat, men aggressionsforbrydelsen forudsætter, at en hel stat er involveret.

Den nok største uenighed blandt staterne handlede om, hvorvidt Domstolen skulle kunne dømme aggressionsforbrydelsen med eller uden indblanding fra FN's Sikkerhedsråd. ICC er normalt uafhængig af Sikkerhedsrådet og kan indlede sager, når enten en medlemsstats regering eller ICC's egen anklager sætter processen i gang. Men spørgsmålet var, om dette også kunne gælde i forhold til aggressionsforbrydelsen - mod dette argumenterede især de fem permanente medlemmer af Sikkerhedsrådet, fordi de mente, at FN-pagten nødvendiggjorde, at Sikkerhedsrådet fik en afgørende rolle i denne sammenhæng. FN-pagten er bindende for alle ICC medlemslande, fordi de også er medlem af FN, og pagten giver Sikkerhedsrådet et primært ansvar for spørgsmål om fred og sikkerhed og derunder falder selvfølgelig også spørgsmål omkring aggressionsforbrydelsen. Forud for Kampala-mødet stod det fuldstændig uklart, hvordan denne position skulle forenes med den af mange andre lande, der ikke ville give Sikkerhedsrådet en bestemmende rolle.

Der blev forhandlet både i plenum og i små grupper, i møder med de europæiske, afrikanske og andre grupperinger, men også bilateralt li- 
gesom blandt Sikkerhedsrådslandene og udviklingslandene. Jo længere statuskonferencen varede, jo større blev presset at få produceret et resultat, og jo længere trak møderne ud. Forhandlingerne blev selvfølgelig præget af de fem permanente medlemmer af Sikkerhedsrådet, fordi aggressionsforbrydelsen vedrører magtforholdene i det internationale system. Samtidigt gjorde forhandlingerne det meget tydeligt, at Sikkerhedsrådets sammensætning ikke længere afspejler magtfordelingen på repræsentativ vis. Især lande som Brasilien og Sydafrika demonstrerede, at en mulig løsning skulle involvere dem. En anden dynamik, der skulle tages højde for, var at et stort flertal af ICC's medlemslande ikke var interesseret $i$ at give Sikkerhedsrådet en afgørende rolle, fordi mange anså det for ensbetydende med, at ICC vil skrumpe til et politisk instrument i Sikkerhedsrådets hænder. Også i den europæiske gruppe var flertallet anført af Tyskland mod at give Sikkerhedsrådet en særlig rolle.

Selv på statuskonferencens allersidste dag var det ikke mange, der troede, man ville kunne overkomme disse uenigheder. Men det lykkedes. Kl. 1.30 om morgenen den sidste dag fremsatte formanden for Kampala-mødet et forslag, der skulle vedtages med konsensus, dvs. uden egentlig afstemning. Formanden, Liechtensteins kompetente FN-ambassadør, Christian Wenaweser, hav- de forhandlet dette stykke papir på en række små møder med de permanente medlemmer af Sikkerhedsrådet, Brasilien, repræsentanter for den afrikanske gruppe og et par andre, og var på dette tidspunkt åbenbart nået frem til, at forslaget kunne vedtages.

Alligevel var stemningen i dette øjeblik yderst anspændt; mange i salen var ikke klar over, om alle kunne acceptere forslaget og frygtede, at der måske ville komme en afstemning - og ville man så for eksempel som europæisk land stemme mod Frankrig og Storbritannien og isolere dem? Ville dette styrke ICC?

Heldigvis kom der ingen afstemning. Efter et øjeblik, der virkede meget langt på alle forhandlingsdeltagere, og et japansk indlæg, som først lød som om Japan ikke vil kunne tilslutte sig løsningen, slog formanden hammeren i bordet og meddelte "it is hereby adopted".

\section{Historiske skridt}

Og dette betød, der var lige blevet skrevet historie: for første gang siden Nürnberg-tribunalet efter Anden Verdenskrig var der igen en realistisk mulighed for at straffe dem, der igangsætter ulovlige krige.

Hvad aggressions-forbrydelsen præcis omfatter, er en kompliceret historie. Det står dog klart fra teksten og forhandlingerne, at forbrydelsen kun skal omfatte de mest alvorlige overtrædelser af FN-pagtens 
forbud mod magtanvendelse. Som eksempel henvises til Nazitysklands overfald på Polen i 1939 eller Iraks angreb mod Kuwait i 1990. Om NATOs intervention in Kosovo i 1999 eller USA's og koalitionens angreb mod Irak i 2003 falder under aggressionsforbrydelsen besvares forskelligt af forskellige lande, men efter forfatterens egen opfattelse er det ikke tilfælde. Men fremover bliver det op til Domstolen at foretage denne vurdering. ICC skal i denne forbindelse kun retsforfølge dem, der kan træffe beslutningen, ikke den enkelte fodsoldat, der udfører ordren.

Inden det kommer så langt, vil der gå nogle år. Beslutningen fra Kampala siger, at aggressionsforbrydelsen tidligst kan finde anvendelse fra 2017, og dette først kan ske, når ICC's medlemslande med 2/3 flertal på dette tidspunkt har bekræftet beslutningen, og minimum 30 ICC medlemslande har ratificeret aggressionsforbrydelsen ved deres nationale parlament. Desuden vil forbrydelsen kunne omfatte ICC medlemslande, dvs. hvis et land, der ikke er tiltrådt ICC-statutten endnu (som for eksempel USA), invaderer et andet land - uanset om dette er ICC medlem eller ej - så kan ICC's anklager ikke rejse tiltale mod dette lands ledelse under aggressionsforbrydelsen.

Det står ikke helt klart, om aggressionsforbrydelsen til gengæld kommer til at gælde for alle 113 ICC medlemslande, så snart bare 30 ICC lande har ratificeret definitionen. Hvis dette er tilfælde, så kan dem, der ønsker det, vælge fra ved at afgive en såkaldt 'opt out' erklæring en mulighed som for eksempel Storbritannien og Frankrig kunne tænkes at tage i brug. Men det ville selvfølgelig i hvert tilfælde rejse en diskussion om, hvorvidt og hvorfor et land virkelig mener, de skal fritages for ICC's kompetence vedrørende aggressionsforbrydelsen. Sikkerhedsrådet har i pakken, som blev vedtaget i Kampala, kun fået en begrænset rolle: det kan bede Domstolen om at igangsætte en undersøgelse, men Sikkerhedsrådet er ikke alene om dette.

ICC's anklager kan på egen hånd, efter grønt lys fra dommerne, rejse en sag omkring aggressionsforbrydelsen - og dette er ikke mindre end en revolution i folkeretten. Sikkerhedsrådet har ellers siden 1945 ikke været konfronteret med en traktat, der ikke giver Rådet en særlig rolle, og at dette nu sker i form af ICC-statutten og i person af en uafhængig anklager er helt uset. Det næste skridt bliver nu at afvente, hvornår de første ICC medlemslande går i gang med at ratificere aggressionsforbrydelsen derhjemme.

\section{Efter Kampala}

De forskellige aktører - både delegationer fra medlemslande, men også de talrige repræsentanter fra 
ikke-medlemslande, ICC og NGO'er - kom med meget forskellige målsætninger til Kampala, faktisk så forskellige ideer, at mange tvivlede på, statuskonferencen kunne blive en succes. Alligevel kom der resultater - store resultater. Det skyldes, at de afgørende stater til sidst indså, at Domstolen ellers kunne blive svækket, ligesom en fiasko i Kampala kunne have ødelagt stemningen blandt staterne i lang tid. I denne situation blev alle regeringer nødt til at justere deres oprindelige positioner og at rykke hen mod en konsensus. Men hvordan ser regnskabet ud efter Kampala? Hvem prægede evalueringen, og hvem kan betragte sig som vinder efter 14 dages forhandlinger?

Det første spørgsmål i denne sammenhæng er, om det blev en succes at afholde ICC's første store forhandlingsrunde siden dens oprettelse i Afrika. Svaret er todelt. Selve afholdelsen gik ikke uden logistiske problemer, men alt $i$ alt løste Uganda opgaven som vært på fornem vis. Lidt skuffende var det dog, at Kampala ikke formåede at tiltrække særlig mange regeringsmedlemmer som delegationsledere for de enkelte lande - de fleste ICC medlemslande, herunder langt de fleste EU lande, blev repræsenteret af højtstående embedsmænd. Selvfølgelig har COP15 mødet i København demonstreret, at en prominent deltagerkreds ikke er ensbetydende med strålende resultater eller blot et no- genlunde resultat - men havde flere ministre deltaget i statuskonferencen, ville dette utvivlsomt have sendt et signal om Domstolens betydning. Et andet, måske endnu vigtigere kritikpunkt er, at en af de centrale overvejelser bag at afholde mødet i Uganda var at konfrontere de mange eksperter og diplomater, der ellers diskuterer ICC's arbejde i hovedstædernes kontorer, et konferencecentre i Haag eller FN-bygningen i New York, med hvad Domstolen egentligt handler om: ofrene for krigsforbrydelser og forbrydelser mod menneskeheden. At møde en 17-årig pige med en lille baby på armen og at høre denne piges fortællinger om at se sine forældre blive nedslagtet, at blive bortført, at blive voldtaget og at blive tvunget til at myrde andre som børnesoldat for den ugandiske Lord Resistance Army gør uslettelig indtryk. Og sætter ICC's arbejde og de mange langvarige diskussioner blandt medlemslande derom i perspektiv.

\section{Fjernt fra ofrene}

Det lykkedes desværre ikke under statuskonferencen at give mange deltagere denne oplevelse. I stedet blev mødet afholdt bag to sikkerhedsbarrierer i et betagende smukt resort ved Victoriasøen, så de fleste udenlandske gæster ikke engang fik set Kampala eller så meget som et enkelt offer. ICC arrangerede under statuskonferencen en en-dags rejse 
til Bunia i den Demokratiske Republik Congo for at mødes med ofre $o g$ for at høre deres historier og forventninger mod ICC - men kun omkring 30 ud af over 2.000 deltagere kunne komme med på dette besøg og lære om Domstolens udfordringer.

Et andet vigtigt motiv bag at udpege Uganda som mødested var at lægge låg på diskussionen om, hvorvidt Domstolen er anti-afrikansk en tilbagevendende kritik fremsat især af afrikanske regimer, der selv krænker menneskerettighederne. Efter Rom, Haag og New York skulle turen derfor nu gå til Kampala for at demonstrere, at ICC også er en afrikansk anliggende, med afrikansk indflydelse. Ideen var god, men lader til kun at have fungeret i begrænset omfang. Der, hvor den fungerede, var under forhandlingerne. Her spillede en række afrikanske lande en meget aktiv og vigtig rolle; dette gjaldt både for de lande som Sydafrika, der under 'stocktaking' segmentet varetog rollen som 'focal point', men også og især under de intensive forhandlinger omkring definitionen af aggressionsforbrydelsen, hvor Sydafrika, Uganda og andre var tæt involverede. Men det er desværre kun den ene side af historien.

Få uger efter statuskonferencen var afholdt og diskussionerne i Kampala omkring samarbejde med Domstolen afsluttet, bekræftede den Afrikanske Union (AU) på et topmøde
- som ironisk nok blev afholdt på samme sted uden for Kampala - at AU medlemslande ikke skulle samarbejde med Domstolen i sagen omkring den sudanesiske præsident AlBashir. Det er langt fra alle afrikanske regeringer, der ligger på denne linje, men beslutningsprocessen i den Afrikanske Union er en kompliceret størrelse, og det lykkedes altså nogle ICC-kritiske regeringer at få denne beslutning igennem. Det blev endnu værre i slutningen af august, da Kenya som er ICC medlemsland, udførte AU's beslutning og inviterede præsident Al-Bashir til en festlighed for at markere vedtagelsen af landets nye forfatning. Dette er en grov overtrædelse af Kenyas pligter under ICC-statutten og den resolution FN's Sikkerhedsråd i 2005 vedtog for at igangsætte ICC's arbejde omkring Darfur.

Bashirs tilstedeværelse i Nairobi har høstet entydig fordømmelse fra Domstolen, EU og en række vestlige regeringer inklusive præsident Obama - men skaden er sket: et afrikansk ICC medlemsland har få uger efter statuskonferencen inviteret en person, som Domstolen eftersøger for alle tre ICC-forbrydelser, deriblandt folkedrab, til en national festlighed. Den officielle kenyanske forklaring lød, at Sudan er et naboland, og at den Afrikanske Union havde påbudt, at ICC's arrestordre mod Bashir skal tilsidesættes. Statuskonferencen og dens diskussioner omkring samarbejde med Domsto- 
len i forhold til arrestordre havde åbenbart ingen effekt på den kenyanske ledelse.

Når ICC bliver kritiseret for at være anti-afrikansk, bliver det ofte kædet sammen med, at Domstolen ikke kan foretage sig noget i forhold til angivelige overtrædelser af den internationale strafferet begået af USA - USA er fortsat ikke medlem af ICC-statutten. Samtidigt har der de sidste år været tilnærmelser til Domstolen fra amerikansk side, tilnærmelser der allerede blev indledt under Bush- administrationen. Det var derfor med en vis spænding, ICC medlemslande ventede, hvordan USA vil agere under statuskonferencen, som var åben for alle FNmedlemmer og derfor selvfølgelig også for USA. Faktisk deltog en hel række lande, der ikke er ICC-medlemmer, som Rusland, Kina, Tyrkiet og Israel, aktivt i mødet. USA viste sin stor interesse i Kampala-konferencen og sendte den klart største delegation af alle deltagende lande: 25 amerikanske diplomater fra udenrigsministeriet og Pentagon samt rådgivere fra US Senatet troppede op til statuskonferencen. USdelegationen blev ledt af den højeste juridiske rådgiver til den amerikanske udenrigsminister og tilsvarende fra Pentagon.

Under selve statuskonferencen gjorde USA det meget tydeligt, at de deler målsætningen om at holde dem, der står for grove overtrædelser af menneskerettighederne, an- svarlige. USA havde indlæg under de forskellige debatter, men var også med til at arrangerede et møde om, hvordan retsopgøret i relevante lande kunne styrkes for at bekæmpe straffrihed. Den største amerikanske interesse gjaldt dog - ikke så overraskende - forhandlingerne omkring aggressionsforbrydelsen. USA led under, at man de sidste otte år ikke havde deltaget i forhandlingerne (Bush-administrationen ville tydeliggøre sin skepsis over for dette foretagende), og derfor havde USA ikke haft noget indflydelse på, hvordan forhandlingsudkastet så ud. Desuden var de fleste andre lande af den opfattelse, at USA ikke på et så sent tidspunkt kunne komme og gennemtvinge større ændringer. Den amerikanske delegation prøvede alligevel - dels ud fra en oprigtig bekymring over udkastet og de svagheder, USA så i det; dels ud fra en lige så oprigtig bekymring for at denne nye forbrydelse kunne blive relevant for USA's fremtidige udenrigspolitik - men endelig også fordi de ICC-venlige kræfter i Obama-administrationen frygtede, at vedtagelsen af en radikal definition på aggressionsforbrydelse vil skade mulighederne for ethvert samarbejde mellem ICC og USA på grund af den efterfølgende politiske reaktion i USA.

\section{USA's ihærdige indsats}

USA prøvede derfor i Kampala ihærdigt at påvirke processen og 
gjorde en stor indsats for at sikre Sikkerhedsrådet - og derigennem sig selv - en afgørende indflydelse på al anvendelse af aggressionsforbrydelsen ved ICC. Der blev både truet og charmet fra amerikansk side. Det lykkedes dog til sidst som bekendt ikke: USA kunne ikke standse dynamikken eller dominere forhandlingerne, som man måske tidligere ville have kunnet. USA fik dog sammen med de andre permanente medlemmer af Sikkerhedsrådet vedtaget en række vigtige ændringer på definitionen, ikke mindst at denne tidligst kan træde i kraft i 2017 og kun gælder for ICC-medlemslande.

Den amerikanske delegation kunne dermed sælge forhandlingsresultatet derhjemme som en succes - på trods af, at det helt banebrydende for første gang blev accepteret, at det ikke er Sikkerhedsrådet (og dens permanente medlemmer) alene, der bestemmer over krig og fred under folkeretten.

Der var lave forventninger til konferencen i Kampala. For det første tvivlede de fleste på, at der ville kunne opnås enighed omkring aggressionsforbrydelsen, og det var den, der skulle stå i centrum i Kampala. For det andet mente mange iagttagere, at i og med Domstolen ikke engang havde afsluttet en enkel sag endnu, kom konferencen for tidligt til at man kunne foretage en egent- lig review af Domstolens arbejde. Resultatet var dog betydeligt mere positivt end forventet. Mange emner med stor relevans for Domstolens arbejde som for eksempel 'complementarity' blev diskuteret på et højt niveau, men også helt konkret. Det bliver selvfølgelig afgørende at se om staterne, herunder Danmark, følger op på deres engagement op til statuskonferencen, men Kampala har betydet klart fremskridt sammenlignet med de årlige samlinger af ICC's medlemslande i Haag.

Med hensyn til aggressionsforbrydelsen er det centrale spørgsmål, om staterne vil følge op på statuskonferencen ved at ratificere definitionen og bekræfte deres tilslutning i 2017. Men så konkret og tæt på har muligheden for at retsforfølge de ansvarlige for angrebskrige ikke været siden 1945. Den næste krig kommer bestemt - men der er gode chancer for, at ICC's anklager næste gang vil være del af processen.

Martin Mennecke, LL.M., ph.d., er adjunkt i folkeret ved Københavns Universitet. Forsker og underviser i folkeret og international strafferet og har siden 2004 varet med $i$ den danske delegation til møder vedrørende den Internationale Straffedomstol (ICC). Han deltog også $i$ statuskonferencen $i$ Kampala som medlem af den officielle danske delegation. 